\title{
Analisis Pemasaran Komoditas Cabai Rawit Merah di Desa Brajan, Kecamatan Prambanan, Kabupaten Klaten
}

\section{(Marketing Analysis for Red Cayenne Pepper in Brajan Village, Prambanan Sub-District, Klaten District)}

\author{
Hastuti $^{1 *}$, Asri Nidya Angga Sari ${ }^{2}$ \\ (Diterima Juli 2019/Disetujui Mei 2020)
}

\begin{abstract}
ABSTRAK
Kabupaten Klaten adalah salah satu penghasil cabai rawit merah di Indonesia. Desa Brajan merupakan salah satu desa di Kecamatan Prambanan yang memproduksi cabai rawit merah. Desa Brajan memiliki letak yang strategis, yaitu dekat perbatasan provinsi Jawa Tengah, sehingga memiliki jalur saluran pemasaran cabai rawit merah yang sangat beragam. Banyaknya jalur pemasaran memengaruhi harga di tingkat konsumen yang memengaruhi marjin pemasaran. Tujuan penelitian ini adalah menganalisis perbandingan usaha tani anggota dengan non anggota kelompok tani komoditas cabai rawit merah, menganalisis saluran dan fungsi pemasaran komoditas cabai rawit merah, dan menganalisis efisiensi saluran pemasaran cabai rawit merah di Desa Brajan, Kecamatan Prambanan, Kabupaten Klaten. Metode analisis yang digunakan adalah analisis pendapatan, $R / C$ ratio, analisis saluran dan fungsi pemasaran, marjin pemasaran, farmer's share, B/C ratio, dan elastisitas transmisi harga. Hasil penelitian menunjukkan bahwa pendapatan usaha tani cabai rawit merah atas biaya tunai pada petani anggota dan non anggota kelompok tani menguntungkan. Pendapatan atas biaya total pada petani anggota menguntungkan, sedangkan pada petani non anggota mengalami kerugian. Terdapat 12 saluran pemasaran cabai rawit merah di Desa Brajan, dan saluran pemasaran mulai dari petani ke pedagang pengumpul kecamatan ke pedagang eceran ke konsumen akhir merupakan saluran pemasaran yang paling efisien.
\end{abstract}

Kata kunci: B/C ratio, elastisitas transmisi harga, farmer's share, marjin pemasaran, saluran pemasaran

\section{ABSTRACT}

Klaten District is one of the producers of red cayenne pepper in Indonesia. Brajan Village is one of the villages in Prambanan District that produces red cayenne pepper. Brajan Village has a strategic location, which is near the border of Central Java province, so it has a very diverse marketing channel for red cayenne pepper. The number of marketing channels affects the price at the consumer level which affects the marketing margin. This research aims are: to analyze the comparison of member farms with non member farmer groups of red cayenne pepper, to analyze the channels and functions of the red cayenne pepper marketing, and to analyze the efficiency of the red cayenne pepper market in Brajan Village, Prambanan Sub-District, Klaten District. The analysis methods used are income analysis, $\mathrm{R} / \mathrm{C}$ ratio analysis, analysis of channel and function marketing, marketing margin analysis, farmer's share analysis, B/C ratio analysis, and analysis of price transmission elasticity. The results showed that the income of red cayenne pepper farming at the cash cost of member farmers and non-member farmer groups are profitable. Income on total costs to member farmers is profitable, while non member farmers are losses. There are 12 marketing channels for red cayenne pepper in Brajan Village, and the marketing channels in the form of farmers to sub district collectors to retail traders to final consumers are the most efficient marketing channels.

Keywords: B/C ratio, farmer's share, marketing channel, marketing margin, price transmission elasticity

\section{PENDAHULUAN}

Sektor pertanian merupakan salah satu sektor yang memberikan kontribusi yang besar dalam perekonomian nasional, dalam penyerapan tenaga kerja dan pemasukan devisa non migas. Pada tahun 2018

${ }^{1}$ Departemen Ekonomi Sumberdaya dan Lingkungan, Fakultas Ekonomi dan Manajemen, Institut Pertanian Bogor, Kampus IPB Darmaga, Bogor 16680

2 Mahasiswa Departemen Ekonomi Sumberdaya dan Lingkungan, Fakultas Ekonomi dan Manajemen, Institut Pertanian Bogor, Kampus IPB Darmaga, Bogor 16680

* Penulis Korespondensi: Email: hastutisiregar@gmail.com kontribusi sektor pertanian secara luas meliputi sektor kehutanan dan perikanan terhadap Produk Domestik Bruto (PDB) Indonesia sebesar $12,81 \%$ dengan harga tahun dasar 2010. Kontribusi subsektor pertanian tanaman hortikultura pada tahun 2018 dengan harga dasar tahun 2010 sebesar $1,47 \%$ dari total PDB keseluruhan (Kementerian Pertanian 2019). Hal ini sesuai dengan tingginya jumlah konsumsi komoditas hortikultura terutama jenis sayur-sayuran oleh penduduk Indonesia. Di antara komoditas pertanian yang ada di Indonesia, cabai merupakan komoditas holtikultura jenis sayur-sayuran yang dibutuhkan oleh hampir semua orang dari berbagai kalangan. 
Menurut Sunarjono (2009), ada dua golongan tanaman cabai yang terkenal, yaitu cabai besar dan cabai kecil. Cabai yang termasuk dalam golongan cabai kecil ialah cabai rawit. Cabai rawit merupakan salah satu komoditi hortikultura yang sangat dibutuhkan oleh hampir semua orang dari berbagai lapisan masyarakat (Ardian et al. 2017). Banyaknya permintaan masyarakat akan cabai rawit sering menyebabkan kenaikan harga komoditas ini. Menurut Sondakh \& Jefrry (2017), sekalipun ada kecenderungan peningkatan kebutuhan, permintaan terhadap cabai rawit untuk kebutuhan sehari-hari berfluktuasi, yang disebabkan tingkat harga yang terjadi di pasar eceran.

Lahan pertanian di Indonesia yang cukup luas didukung kondisi alam yang tropis merupakan salah satu faktor yang memengaruhi petani dalam meningkatkan hasil produksi cabai rawit. Berdasarkan Pusdatin (2017), diperoleh data bahwa cabai rawit memiliki pertumbuhan produksi dari tahun 2015 ke tahun 2016 sebesar $5,29 \%$, pertumbuhan luas panen sebesar $1,45 \%$, pertumbuhan produktivitas sebesar $3,80 \%$, hal ini menggambarkan pertumbuhan produksi cabai rawit yang positif.

Kabupaten Klaten merupakan salah satu kabupaten di Indonesia yang memproduksi cabai rawit. Kecamatan Prambanan merupakan salah satu kecamatan di Kabupaten Klaten yang memproduksi cabai rawit tertinggi kedua setelah Kecamatan Jatinom, yaitu dengan luas panen sebesar 330.00 ha, rata-rata produksi sebesar $6,21 \mathrm{kw} / \mathrm{ha}$, dan produksi sebesar 2050 Kw (BPS Kabupaten Klaten 2018). Desa Brajan merupakan salah satu desa di Kecamatan Prambanan yang menjadi sentra produksi komoditas cabai rawit merah.

Desa Brajan memiliki letak yang strategis, yaitu dekat perbatasan Provinsi Jawa Tengah, sehingga memiliki jalur saluran pemasaran cabai rawit merah yang sangat beragam. Tingkat produktivitas cabai rawit merah di Desa Brajan sangat terkait dengan penggunaan faktor-faktor produksi. Tingkat produktivitas tiap petani cabai rawit merah di Desa Brajan dipengaruhi oleh besar kecilnya skala usaha tani yang dijalankan dalam pengusahaan komoditas cabai rawit merah. Jumlah produktivitas yang dihasilkan memengaruhi tingkat pendapatan usaha tani yang diterima petani cabai rawit merah. Waktu tanam dan luas lahan penanaman cabai rawit merah di Desa Brajan yang berbeda-beda mengakibatkan jumlah produksi dan pendapatan yang diterima petani usaha tani cabai rawit merah di Desa Brajan pun berbeda-beda.

Fluktuasi harga cabai rawit merah sering dirasakan petani di Kecamatan Prambanan. Peningkatan harga cabai rawit dikarenakan tingginya permintaan dan sedikitnya pasokan cabai rawit (Arum 2018). Peningkatan terjadi biasanya menjelang hari besar keagaman dan tahun baru. Penurunan harga cabai rawit yang dirasakan petani di Kecamatan Prambanan disebabkan oleh tingginya jumlah cabai rawit saat musim panen (Purnama 2017). Desa Brajan meru- pakan salah satu desa yang memproduksi cabai rawit di Kecamatan Prambanan sehingga turut mengalami fluktuasi harga. Berdasarkan pemaparan dari latar belakang dan perumusan masalah, maka tujuan yang ingin dicapai dari penelitian ini adalah 1) Menganalisis perbandingan usaha tani anggota dan non anggota kelompok tani komoditas cabai rawit merah, 2) Menganalisis saluran dan fungsi pemasaran komoditas cabai rawit merah, dan 3) Menganalisis efisiensi pemasaran cabai rawit merah di Desa Brajan, Kecamatan Prambanan, Kabupaten Klaten.

\section{METODE PENELITIAN}

\section{Lokasi dan Waktu Penelitian}

Daerah penelitian ditentukan dengan menggunakan metode secara sengaja (purposive method) dan daerah lokasi penelitian adalah di Kabupaten Klaten. Desa Brajan merupakan lokasi pengambilan sampel petani cabai rawit merah. Hal ini karena Kabupaten Klaten merupakan salah satu daerah penghasil cabai rawit merah di Indonesia, baik dalam hal luas tanam, luas panen, produksi, dan produktivitas per luas panen. Desa Brajan terletak di Kecamatan Prambanan yang merupakan salah satu kecamatan yang memproduksi cabai rawit merah di Kabupaten Klaten. Waktu pengumpulan data primer dilakukan pada bulan Januari-Maret 2019.

\section{Jenis dan Sumber Data}

Data yang digunakan dalam penelitian ini diperoleh dari data primer dan sekunder. Data primer diperoleh secara langsung di lapang, baik melalui pengamatan langsung, dengan menggunakan kuesioner dan wawancara pada sejumlah petani dan pedagang pengumpul yang terlibat di Desa Brajan, Kecamatan Prambanan, Kabupaten Klaten. Data sekunder merupakan data yang diperoleh tanpa pengamatan langsung di lapangan dan merupakan data yang diperoleh dari studi kepustakaan seperti: Kementerian Pertanian, Badan Pusat Statistik Kabupaten Klaten, dan Kantor Desa Brajan.

\section{Metode Pengambilan Sampel}

Responden dalam penelitian ini adalah petani yang melakukan usaha tani cabai rawit merah. Responden petani sebanyak 39 yang terdiri dari 29 orang petani anggota kelompok tani dan sepuluh petani non anggota kelompok tani. Sejumlah 29 orang petani anggota kelompok tani ditentukan dengan metode purposive sampling karena sampel dipilih secara sengaja dengan kriteria tertentu, yaitu tingkat homogenitas petani, sedangkan sepuluh petani non anggota kelompok tani ditentukan menggunakan metode sensus keseluruhan populasi.

Responden pedagang sebanyak 14 menggunakan metode snowball sampling yang dianggap telah mewakili kondisi saluran pemasaran cabai rawit merah di Desa Brajan. Responden pedagang menggunakan 
metode snowball sampling karena sampel pedagang diperoleh dari responden ke responden lainnya. Snowball sampling dimulai dari beberapa orang petani di Desa Brajan kemudian meluas berdasarkan saluran pemasaran yang ada.

\section{Metode Analisis dan Pengolahan Data}

Analisis penelitian ini menggunakan pendekatan metode kualitatif dan metode kuantitatif. Metode analisis dalam penelitian ini dapat dilihat pada Tabel 1 .

\section{Analisis Perbandingan Usaha Tani}

Terdapat dua indikator yang digunakan untuk menghitung analisis perbandingan usaha tani cabai rawit merah di Desa Brajan, yaitu analisis pendapatan dan analisis $R / C$ ratio. Berikut ini dijelaskan kedua analisis tersebut.

\section{- Analisis pendapatan usaha tani}

Menurut Soekartawi (2006) penerimaan usaha tani merupakan perkalian antara produksi yang diperoleh dengan harga jual. Secara matematis dirumuskan sebagai berikut:

$$
\mathrm{TR}=\mathrm{Y} . \mathrm{PY}
$$

Keterangan:

$\mathrm{TR}=$ Total penerimaan petani cabai rawit merah (Rp/musim tanam)

$\mathrm{Y}=$ Produksi yang diperoleh dari suatu usaha tani cabai rawit merah $(\mathrm{kg} / \mathrm{musim}$ tanam)

$\mathrm{PY}_{\mathrm{Y}}=$ Harga produksi cabai rawit merah $(\mathrm{Rp} / \mathrm{kg})$.

Data harga cabai rawit merah yang digunakan merupakan harga rata-rata dari seluruh responden pada satu waktu (cross section), yaitu bulan JanuariMaret 2019 untuk musim tanam tahun 2018-2019.

Menurut Soekartawi (2006), pendapatan (keuntungan) usaha tani cabai rawit merah adalah selisih penerimaan dengan semua biaya produksi cabai rawit merah, dirumuskan sebagai berikut:

$$
\pi=Y \cdot P_{Y}-\Sigma X_{i} \cdot P x_{i}-B T T
$$

Keterangan:

$\pi \quad=$ Pendapatan usaha tani petani cabai rawit merah (Rp/musim tanam)
$\mathrm{Y}=$ Jumlah produksi cabai rawit merah $(\mathrm{kg} / \mathrm{musim}$ tanam)

$\mathrm{PY}_{\mathrm{Y}}=$ Harga satuan produksi cabai rawit merah $(\mathrm{Rp} / \mathrm{kg})$

$\mathrm{X}_{\mathrm{i}}=$ Faktor produksi/input variabel (satuan tertentu)

$\mathrm{Px}_{\mathrm{i}}=$ Harga faktor produksi/input variabel (Rp/satuan)

$\mathrm{BTT}=$ Biaya tetap total dari usaha tani cabai rawit merah (Rp)

$\mathrm{i}=$ Faktor produksi/input variabel ke 1, 2, 3...n

\section{- $R / C$ ratio (Return Cost ratio)}

Perhitungan efisiensi usaha tani digunakan analisis $R / \mathrm{C}$ ratio atau dikenal sebagai perbandingan (nisbah) antara penerimaan dan biaya. Secara matematik, dapat dirumuskan sebagai berikut (Soekartawi 2006):

$$
R C R=\frac{R}{C}
$$

Keterangan:

$R C R=$ Return cost ratio

$\mathrm{R}=$ = Penerimaan petani cabai rawit merah

(Rp/musim tanam)

C = Biaya yang dikeluarkan petani cabai rawit merah (Rp/musim tanam)

\section{Analisis Saluran dan Fungsi Pemasaran}

Analisis saluran pemasaran cabai rawit merah dilakukan dengan menelusuri saluran distribusi mulai dari petani sebagai produsen hingga ke konsumen akhir. Analisis fungsi pemasaran dapat dilihat dari fungsi pemasaran yang dilakukan oleh lembaga pemasaran. Fungsi pemasaran terdiri dari fungsi pertukaran, fisik, dan fasilitas.

\section{Analisis Efisiensi Saluran Pemasaran}

Dalam penelitian terdapat empat indikator yang digunakan untuk menganalisis efisiensi saluran pemasaran, yaitu marjin pemasaran, farmer' share, $B / C$ ratio, dan elastisitas transmisi harga. Berikut ini dijelaskan terkait dengan keempat analisis tersebut.

\section{- Analisis marjin pemasaran}

Marjin pemasaran adalah selisih harga yang

\begin{tabular}{|c|c|c|}
\hline Tujuan penelitian & Data & Analisis \\
\hline $\begin{array}{l}\text { Menganalisis perbandingan antara usaha } \\
\text { tani petani anggota dan non anggota } \\
\text { kelompok tani komoditas cabai rawit merah di } \\
\text { Desa Brajan, Kecamatan Prambanan, } \\
\text { Kabupaten Klaten }\end{array}$ & $\begin{array}{l}\text { Jenis data: primer } \\
\text { Sumber: petani cabai rawit } \\
\text { merah }\end{array}$ & $\begin{array}{l}\text { Metode: Analisis pendapatan dan } R / C \\
\text { ratio }\end{array}$ \\
\hline $\begin{array}{l}\text { Menganalisis saluran dan fungsi pemasaran } \\
\text { komoditas cabai rawit merah di Desa Brajan, } \\
\text { Kecamatan Prambanan, Kabupaten Klaten }\end{array}$ & $\begin{array}{l}\text { Jenis data: primer } \\
\text { Sumber: petani dan } \\
\text { pedagang cabai rawit merah }\end{array}$ & Analisis saluran dan fungsi pemasaran \\
\hline $\begin{array}{l}\text { Menganalisis efisiensi pemasaran cabai rawit } \\
\text { merah di Desa Brajan, Kecamatan } \\
\text { Prambanan, Kabupaten Klaten }\end{array}$ & $\begin{array}{l}\text { Jenis data: primer } \\
\text { Sumber: petani dan } \\
\text { pedagang cabai rawit merah }\end{array}$ & $\begin{array}{l}\text { Metode: marjin pemasaran, farmer's } \\
\text { share, } B / C \text { ratio, dan elastisitas transmisi } \\
\text { harga }\end{array}$ \\
\hline
\end{tabular}
dibayar diantara lembaga pemasaran (Kohls \& Uhl

Tabel 1 Matriks keterkaitan antara tujuan penelitian, data, dan analisis 
2002). Limbong \& Sitorus (1987) mendefinisikan marjin tataniaga sebagai perbedaan harga yang dibayarkan konsumen dengan harga yang diterima oleh produsen, marjin pemasaran setiap lembaga pemasaran dapat dirumuskan sebagai berikut:

$$
\begin{aligned}
\mathrm{M}_{\mathrm{i}} & =\mathrm{P}_{r i}-\mathrm{P}_{f i} \\
= & \mathrm{C}_{i}-\Pi_{i} \\
= & \mathrm{P}_{j i}-\mathrm{P}_{b i} \\
\text { sehingga: } & \mathrm{MT}^{\mathrm{n}}=\sum_{\mathrm{i}=1} \cdot \mathrm{M}_{i}
\end{aligned}
$$

Keterangan:

$\mathrm{M}_{\mathrm{i}} \quad$ = Marjin pemasaran cabai rawit merah pada pasar tingkat ke-i (Rp/kg)

$\mathrm{P}_{r i}=$ Harga jual cabai rawit merah pada tingkat lembaga ke-i $(\mathrm{Rp} / \mathrm{kg})$

$\mathrm{P}_{f i}=$ Harga beli cabai rawit merah pada tingkat lembaga ke-i (Rp/kg)

$\mathrm{C}_{i}=$ Biaya pemasaran cabai rawit merah pada tingkat lembaga ke-i (Rp/kg)

$\pi_{i}=$ Keuntungan lembaga pemasaran cabai rawit merah pada tingkat ke-i $(\mathrm{Rp} / \mathrm{kg})$

$\mathrm{P}_{j i} \quad$ = Harga penjualan cabai rawit merah untuk lembaga pemasaran ke-i (Rp/kg)

$\mathrm{P}_{b i}=$ Harga pembelian cabai rawit merah untuk lembaga pemasaran ke-i (Rp/kg)

$\mathrm{n}$ = Jumlah lembaga pemasaran cabai rawit merah

i = Lembaga pemasaran

\section{- Farmer's Share}

Farmer's share adalah perbandingan dari harga yang diterima petani produsen dengan harga yang dibayar oleh konsumen yang dinyatakan dalam persentase (Kohls \& Uhl 2002). Hasil farmer's share akan menunjukkan apakah pemasaran memberikan balas jasa yang seimbang kepada semua pihak yang terlibat dalam pemasaran cabai rawit merah. Secara matematis farmer's share untuk saluran pemasaran cabai rawit merah dirumuskan dengan:

$$
F^{\prime} S=\frac{P_{f}}{P_{r}} \times 100 \%
$$

Keterangan:

$$
\begin{aligned}
F^{\prime} S= & \text { Farmer's share }(\%) \\
\mathrm{P}_{f} & =\text { Harga di tingkat petani cabai rawit merah } \\
& (\text { Rp } / \mathrm{kg}) \\
\mathrm{P}_{r} & =\text { Harga di tingkat retail (konsumen akhir) } \\
& \text { cabai rawit merah }(\mathrm{Rp} / \mathrm{kg})
\end{aligned}
$$

\section{- $\quad B / C$ Ratio (Rasio keuntungan terhadap biaya)}

Perhitungan rasio keuntungan terhadap biaya digunakan untuk menganalis tingkat efisiensi saluran pemasaran cabai rawit merah. Secara matematis, rasio penyebaran keuntungan terhadap biaya dapat dirumuskan sebagai berikut (Limbong \& Sitorus 1987):

$$
B / C \text { ratio }=\frac{\pi_{i}}{C_{i}}
$$

Keterangan:

$B / C$ ratio $=$ Rasio keuntungan biaya lembaga pemasaran cabai rawit merah ke-i

$\pi_{i}=$ Keuntungan lembaga pemasaran cabai rawit merah ke-i $(\mathrm{Rp} / \mathrm{kg})$

$C_{i} \quad=$ Biaya pemasaran lembaga pemasaran cabai rawit merah ke-i ( $\mathrm{Rp} / \mathrm{kg})$ $=1,2,3 \ldots n$

\section{- Elastisitas Transmisi Harga}

Untuk mencerminkan seberapa jauh perubahan harga di tingkat pasar petani cabai rawit merah ditransmisikan ke perubahan harga di pasar konsumen akhir cabai rawit merah diperlukan perhitungan elastisitas transmisi harga. Analisis transmisi harga akan memberikan gambaran bagaimana harga yang dibayarkan produsen ditransmisikan kepada konsumen. Hubungan elastisitas harga di tingkat produsen dan tingkat konsumen dapat dilihat elastisitas transmisi harganya, yaitu perubahan harga di tingkat produsen terhadap perubahan harga di tingkat konsumen (Azzaino 1982). Elastisitas transmisi harga, yaitu persentase perubahan harga di tingkat retailer (konsumen akhir) dibagi dengan persentase perubahan harga di tingkat petani. Adapun secara matematis elastisitas transmisi harga dapat dirumuskan sebagai berikut (Asmarantaka 2014):

$$
\mathrm{ET}=\frac{\mathrm{dP}_{r}}{\mathrm{dP}_{f}} \times \frac{\mathrm{P}_{f}}{\mathrm{P}_{r}}
$$

Keterangan:

$\mathrm{ET}=$ Elastisitas transmisi harga cabai rawit merah

$\mathrm{P}_{r}=$ Harga di tingkat konsumen cabai rawit merah (Rp/kg)

$\mathrm{P}_{f}=$ Harga di tingkat petani produsen cabai rawit merah $(\mathrm{Rp} / \mathrm{kg})$

$\mathrm{dP}_{r}=$ Perubahan harga di tingkat konsumen cabai rawit merah $(\mathrm{Rp} / \mathrm{kg})$

$\mathrm{dP}_{f}=$ Perubahan harga di tingkat petani produsen cabai rawit merah $(\mathrm{Rp} / \mathrm{kg})$

\section{HASIL DAN PEMBAHASAN}

\section{Analisis Perbandingan Usaha Tani Cabai Rawit Merah}

Dalam penelitian ini dilakukan analisis perbandingan usaha tani cabai rawit untuk membedakan usaha tani cabai rawit merah petani anggota kelompok tani dan non anggota kelompok tani. Analisis perbandingan usaha tani yang dihitung pada pola satu musim tanam rata-rata, yaitu selama delapan bulan dengan luas lahan satu hektar. Luas Iahan usaha tani cabai rawit merah baik yang dimiliki maupun disewa petani Desa Brajan, Kecamatan Prambanan, Kabupaten Klaten rata-rata adalah 0,23 ha untuk setiap responden anggota, sedangkan 0,20 ha untuk setiap responden non anggota kelompok tani. Dalam analisis pendapatan usaha tani cabai rawit merah, pengeluaran 
biaya selama menjalankan usaha tani digolongkan menjadi dua, yaitu biaya tunai dan biaya diperhitungkan. Biaya tunai merupakan biaya yang dikeluarkan petani selama kegiatan usaha tani berlangsung, yaitu mulai dari penyiapan lahan hingga pemasaran hasil produksi, sedangkan biaya diperhitungkan yaitu biaya non tunai yang biasanya tidak diperhitungkan, oleh petani sebagai biaya yang dikeluarkan. Biaya tunai dalam penelitian ini meliputi biaya bibit, pajak lahan, pestisida, pupuk, pengairan, tenaga kerja luar keluarga, dan biaya transportasi. Biaya diperhitungkan atau biaya non tunai, yaitu terdiri dari tenaga kerja dalam keluarga, penyusutan alat, dan sewa lahan.

\section{Analisis Pendapatan Petani yang Tergabung Kelompok Tani (Poktan)}

Dalam penelitian ini, biaya tunai tetap dalam usaha tani cabai rawit merah, yaitu biaya pajak. Besarnya pajak yang dibayarkan tergantung dari luas lahan yang dimiliki petani dan dibayarkan selama satu musim tanam 8 bulan. Biaya tunai variabel dalam usaha tani cabai rawit merah anggota poktan meliputi biaya bibit, pestisida, pupuk, pengairan, tenaga kerja luar keluarga, dan transportasi. Analisis pendapatan petani anggota dapat dilihat pada Tabel 2.

Berdasarkan Tabel 2, hasil penerimaan petani cabai rawit merah dalam lahan pertanian satu hektar rata-rata dapat menghasilkan produksi cabai rawit merah sebanyak $3.009,17 / 8$ bulan dengan harga ratarata cabai rawit merah pada bulan Februari-Maret 2019 sebesar Rp11.310,34/kg. Rata-rata penerimaan total yang diperoleh petani adalah sebesar Rp34.034.731,27.

Keuntungan yang diperoleh petani poktan atas biaya tunai adalah sebesar Rp8.831.151,00/ha/musim tanam. Keuntungan yang diperoleh petani poktan komoditas cabai rawit merah di Desa Brajan atas biaya total adalah sebesar Rp310.539,53/ha/musim tanam. Pada Tabel 2, $R / C$ ratio atas biaya tunai adalah sebesar 1,35, artinya setiap pengeluaran yang dikeluarkan secara tunai oleh petani anggota poktan sebanyak $\mathrm{Rp} 1,00$ dapat memberikan penerimaan sebanyak Rp1,35 yang artinya usaha tani tersebut menguntungkan atas biaya tunai yang dikeluarkan. $R / C$ ratio atas biaya total adalah sebesar 1,00 , artinya setiap pengeluaran yang dikeluarkan secara tunai maupun non tunai oleh petani anggota poktan sebanyak Rp1,00 memberikan penerimaan sebesar Rp1,01 yang artinya usaha tani petani anggota poktan menguntungkan atas biaya total yang dikeluarkan. Keuntungan yang relatif rendah atas pengeluaran biaya total terjadi dikarenakan tingginya biaya sewa, yaitu sebesar Rp7.941.595,44 dan harga cabai rawit merah pada saat penelitian dilakukan sedang mengalami penurunan.

\section{Analisis Pendapatan Non Anggota Kelompok Tani (Non Poktan)}

Komponen biaya tunai dan non tunai (biaya diperhitungkan) petani cabai rawit merah di Desa Brajan yang non anggota kelompok tani (non poktan) sama dengan komponen biaya petani poktan, akan

Tabel 2 Analisis pendapatan usaha tani cabai rawit merah petani anggota poktan per hektar per musim tanam di Desa Brajan, Kecamatan Prambanan, Kabupaten Klaten pada tahun 2019

\begin{tabular}{|c|c|c|c|c|c|}
\hline Komponen biaya & Jumlah & Satuan & Harga (Rp) & Nilai (Rp) & Persentase (\%) \\
\hline $\begin{array}{l}\text { Penerimaan usaha tani } \\
\text { cabai rawit merah }\end{array}$ & $3.009,17$ & $\mathrm{~kg}$ & $11.310,34$ & $34.034 .731,27$ & \\
\hline Total penerimaan & & & \multicolumn{3}{|c|}{$34.034 .731,27$} \\
\hline Biaya tunai: & & & & & \\
\hline Bibit & $11.771,59$ & Batang & 136,70 & $1.609 .188,64$ & 4,77 \\
\hline Pajak lahan & 8,00 & Bulan & & $275.399,53$ & 0,82 \\
\hline Pestisida & 13,02 & botol (1 L) & $85.426,53$ & $1.112 .229,17$ & 3,30 \\
\hline \multicolumn{6}{|l|}{ Pupuk } \\
\hline ZA & 11,36 & Karung $(50 \mathrm{~kg})$ & $99.552,66$ & $1.131 .047,80$ & 3,35 \\
\hline NPK Phonska & 8,15 & Karung $(50 \mathrm{~kg})$ & $176.254,26$ & $1.436 .343,10$ & 4,26 \\
\hline NPK Mutiara & 4,84 & Karung $(50 \mathrm{~kg})$ & $423.992,11$ & $2.052 .272,52$ & 6,09 \\
\hline Organik & & & & $1.207 .532,05$ & 3,58 \\
\hline Kandang & 23,38 & pick up & $197.136,60$ & $4.608 .254,48$ & 13,66 \\
\hline Pengairan & 14,72 & Kali & $404.118,29$ & $5.950 .293,51$ & 17,64 \\
\hline TKLK & 63,01 & $\mathrm{HOK} /$ musim tanam & $88.584,65$ & $5.581 .717,76$ & 16,55 \\
\hline Transportasi & 27,68 & Liter bensin & $8.645,83$ & $239.301,72$ & 0,71 \\
\hline Total biaya tunai & & & & $25203.580,27$ & 74,73 \\
\hline \multicolumn{6}{|l|}{ Biaya diperhitungkan: } \\
\hline TKDK & 4,02 & HOK/musim tanam & $65.000,00$ & $261.473,21$ & 0,78 \\
\hline Penyusutan alat & & Rp/musim tanam & & $317.542,81$ & 0,94 \\
\hline Sewa lahan & 8,00 & Bulan & $992.699,43$ & $7.941 .595,44$ & 23,55 \\
\hline Total biaya diperhitungkan & & & & $8.520 .611,47$ & 25,27 \\
\hline Jumlah total biaya $(B+C)$ & & & & $33.724 .191,74$ & 100,00 \\
\hline Pendapatan atas biaya tunai & & & & $8.831 .151,00$ & \\
\hline Pendapatan atas biaya total & & & & $310.539,53$ & \\
\hline $\mathrm{R} / \mathrm{C}$ biaya tunai & & & & 1,35 & \\
\hline $\mathrm{R} / \mathrm{C}$ atas biaya total & & & & 1,01 & \\
\hline
\end{tabular}

Keterangan: $\mathrm{HOK}=$ Hari orang kerja. 
tetapi pupuk tidak mengunakan pupuk Organik. Analisis pendapatan petani non poktan dapat dilihat pada Tabel 3 .

Berdasarkan Tabel 3, rata-rata satu hektar lahan per musim tanam dapat menghasilkan produksi sebesar 2.299,78 kg dengan harga jual Rp11.400/kg sehingga penerimaan petani non poktan yaitu sebesar Rp26.217.532,78/ha/musim tanam. Keuntungan yang diperoleh petani non poktan atas biaya tunai yang dikeluarkan yaitu sebesar Rp8.594.335,15/ ha/musim tanam. Keuntungan yang diperoleh petani non poktan atas biaya total (penjumlahan biaya tunai dan biaya diperhitungkan) yang dikeluarkan petani non poktan yaitu sebesar Rp-99.093,91.

Berdasarkan Tabel 3, diperoleh nilai $R / C$ ratio atas biaya tunai sebesar 1,49 , artinya setiap pengeluaran secara tunai oleh petani anggota poktan atau biaya sebanyak Rp1,00 dapat memberikan penerimaan sebanyak Rp1,49 (usaha tani menguntungkan). $R / C$ ratio atas biaya total sebesar $0,99, R / C$ kurang dari 1.00 , menunjukkan usaha tani cabai rawit merah petani non poktan merugi atas biaya total yang dikeluarkan. Hal ini dikarenakan biaya sewa lahan yang cukup tinggi dan harga cabai rawit merah sedang mengalami penurunan saat penelitian dilakukan. Keadaan usaha tani yang merugi atas biaya total hanya dirasakan oleh petani non poktan yang melakukan penyewaan lahan.
Berdasarkan Tabel 2 dan 3, jumlah penjualan hasil produksi per hektar per musim tanam pada petani anggota poktan, yaitu sebesar $3.009,17 \mathrm{~kg}$, jumlah ini lebih tinggi dibandingkan jumlah penjualan petani non anggota poktan, yaitu sebesar $2.299,78 \mathrm{~kg}$. Jumlah penjualan hasil produksi yang lebih tinggi pada petani anggota poktan ini dipengaruhi peran kelompok tani yang memfasilitasi adanya kartu tani guna mendapatkan akses pupuk berdasarkan kuota yang telah ditentukan. Hal ini menyebabkan penggunaan beberapa pupuk pada petani anggota poktan lebih tinggi dibandingkan petani non anggota poktan. Penggunaan jumlah pupuk yang berbeda ini memengaruhi perbedaan jumlah produksi cabai rawit merah yang dihasilkan antara petani anggota poktan dan petani non anggota poktan. Perbedaan hasil produksi ini yang menyebabkan perbedaan jumlah penjualan antara petani anggota poktan dan petani non anggota poktan

\section{Analisis Saluran Pemasaran}

Berdasarkan penelitian yang dilakukan, diperoleh 12 saluran pemasaran cabai rawit merah di Desa Brajan, Kecamatan Prambanan, Kabupaten Klaten. Terdapat 12 saluran pemasaran cabai rawit merah di Desa Brajan, sebagai berikut: 1) Saluran pemasaran ke I: petani-pedagang pengumpul desa-konsumen

Tabel 3 Analisis pendapatan usaha tani cabai rawit merah petani non anggota poktan/ha/musim tanam di Desa Brajan, Kecamatan Prambanan, Kabupaten Klaten pada tahun 2019

\begin{tabular}{|c|c|c|c|c|c|}
\hline Komponen biaya & Jumlah & Satuan & Harga $(R p)$ & Nilai (Rp) & Persentase $(\%)$ \\
\hline $\begin{array}{l}\text { Penerimaan usaha tani cabai } \\
\text { rawit merah }\end{array}$ & $2.299,78$ & $\mathrm{~kg}$ & $11.400,00$ & $26.217 .532,78$ & \\
\hline Total penerimaan & & & \multicolumn{3}{|c|}{$26.217 .532,78$} \\
\hline Biaya tunai & & & & & \\
\hline Bibit & $9.602,55$ & Batang & 170,66 & $1.638 .751,19$ & 6,23 \\
\hline Pajak lahan & 8,00 & Bulan & $67.279,00$ & $538.232,04$ & 2,05 \\
\hline Pestisida & 8,38 & Botol (1 L) & $72.339,44$ & $606.094,29$ & 2,30 \\
\hline \multicolumn{6}{|l|}{ Pupuk } \\
\hline ZA & 11,24 & Karung $(50 \mathrm{~kg})$ & $130.544,29$ & $1.466 .767,60$ & 5,57 \\
\hline NPK Phonska & 5,94 & Karung $(50 \mathrm{~kg})$ & $164.612,54$ & $978.019,26$ & 3,72 \\
\hline NPK Mutiara & 2,38 & Karung $(50 \mathrm{~kg})$ & $413.709,68$ & $986.538,46$ & 3,75 \\
\hline Kandang & 20,87 & pick up & $180.715,93$ & $3.771 .300,37$ & 14,33 \\
\hline Pengairan & 17,60 & Kali & $333.489,74$ & $5.869 .419,41$ & 22,30 \\
\hline TKLK & 8,07 & $\begin{array}{l}\mathrm{HOK} / \text { musim } \\
\text { tanam }\end{array}$ & $190.957,17$ & $1.540 .262,52$ & 5,85 \\
\hline $\begin{array}{c}\text { Transportasi } \\
\text { Total biaya tunai }\end{array}$ & 26,35 & Liter bensin & $8.645,83$ & $\begin{array}{r}227.812,50 \\
17.623 .197,64\end{array}$ & $\begin{array}{r}0,87 \\
66,97\end{array}$ \\
\hline \multicolumn{6}{|l|}{ Biaya diperhitungkan } \\
\hline TKDK & 34,33 & $\begin{array}{l}\mathrm{HOK} / \text { musim } \\
\text { tanam }\end{array}$ & $55.742,82$ & $1.913 .571,43$ & 7,27 \\
\hline Penyusutan alat & & $\begin{array}{l}\text { Rp/musim } \\
\text { tanam }\end{array}$ & & $265.571,92$ & 1,01 \\
\hline Sewa Lahan & 8,00 & Bulan & $814.285,71$ & $6.514 .285,71$ & 24,75 \\
\hline Total biaya diperhitungkan & & & & $8.693 .429,06$ & 33,03 \\
\hline Jumlah total biaya $(B+C)$ & & & & $26.316 .626,70$ & 100,00 \\
\hline Pendapatan atas biaya tunai & & & & $8.594 .335,15$ & \\
\hline Pendapatan atas biaya total & & & & $-99.093,91$ & \\
\hline $\mathrm{R} / \mathrm{C}$ biaya tunai & & & & 1,49 & \\
\hline $\mathrm{R} / \mathrm{C}$ atas biaya total & & & & 0,99 & \\
\hline
\end{tabular}

Keterangan: $\mathrm{HOK}=$ Hari orang kerja. 
pedagang pengumpul desa-pedagang besarkonsumen agen eceran; 3) Saluran pemasaran ke III: petani-pedagang pengumpul desa-pedagang ecerankonsumen akhir; 4) Saluran pemasaran ke IV: petanipedagang pengumpul desa-pedagang pengumpul provinsi-konsumen agen provinsi; 5) Saluran pemasaran $V$ : petani-pedagang pengumpul kecamatankonsumen agen kecamatan; 6) Saluran pemasaran ke VI: petani-pedagang pengumpul kecamatan-pedagang pengumpul kabupaten-konsumen agen kabupaten;7) Saluran pemasaran ke VII: petani-pedagang pengumpul kecamatan-pedagang eceran-konsumen akhir; 8) Saluran pemasaran ke VIII: petani-pedagang pengumpul kecamatan-pedagang pengumpul provinsikonsumen agen provinsi; 9) Saluran pemasaran ke IX: petani-pedagang besar-konsumen agen eceran; 10) Saluran pemasaran ke $\mathrm{X}$ : petani-pedagang besarpedagang pengumpul luar provinsi-konsumen agen luar provinsi; 11) Saluran pemasaran ke XI: petanipedagang besar-pedagang eceran-konsumen akhir; dan 12) Saluran pemasaran ke XII: petani-pedagang eceran-konsumen akhir.

Pola saluran pemasaran cabai rawit merah di Desa Brajan dapat dilihat pada Gambar 1.

\section{Analisis Fungsi Pemasaran}

Setiap lembaga pemasaran yang terlibat dalam saluran pemasaran cabai rawit merah melakukan fungsi pemasaran masing-masing berbeda satu dengan lainnya. Fungsi pemasaran cabai rawit merah di Desa Brajan dilakukan oleh lembaga perantara agar hasil produksi cabai rawit hingga konsumen akhir baik dari dalam Kabupaten Klaten maupun dari luar Kabupaten Klaten. Fungsi pemasaran cabai rawit merah dibedakan menjadi tiga kelompok, yaitu fungsi pertukaran, fisik, dan fasilitas. Adapun fungsi-fungsi pemasaran setiap lembaga pemasaran dapat dilihat pada Tabel 4.

\section{Efisiensi Saluran Pemasaran}

Dalam penelitian ini efisiensi saluran pemasaran cabai rawit merah dihitung menggunakan analisis marjin pemasaran, farmer's share, $\mathrm{B} / \mathrm{C}$ ratio, dan elastisitas transmisi harga. Berikut dijabarkan masingmasing analisis efisiensi pemasaran cabai rawit merah.

\section{- Analisis marjin pemasaran}

Analisis marjin pemasaran digunakan untuk mengetahui marjin yang terjadi di setiap saluran pemasaran cabai rawit merah. Biaya pemasaran dilihat berdasarkan fungsi pemasaran yang dilakukan oleh setiap lembaga pemasaran di lokasi penelitian. Rekapitulasi marjin pemasaran, farmer's share, dan rasio keuntungan terhadap biaya, elastisitas transmisi harga rata-rata per hari per musim tanam pada saluran pemasaran cabai rawit merah dapat dilihat pada Tabel 5.

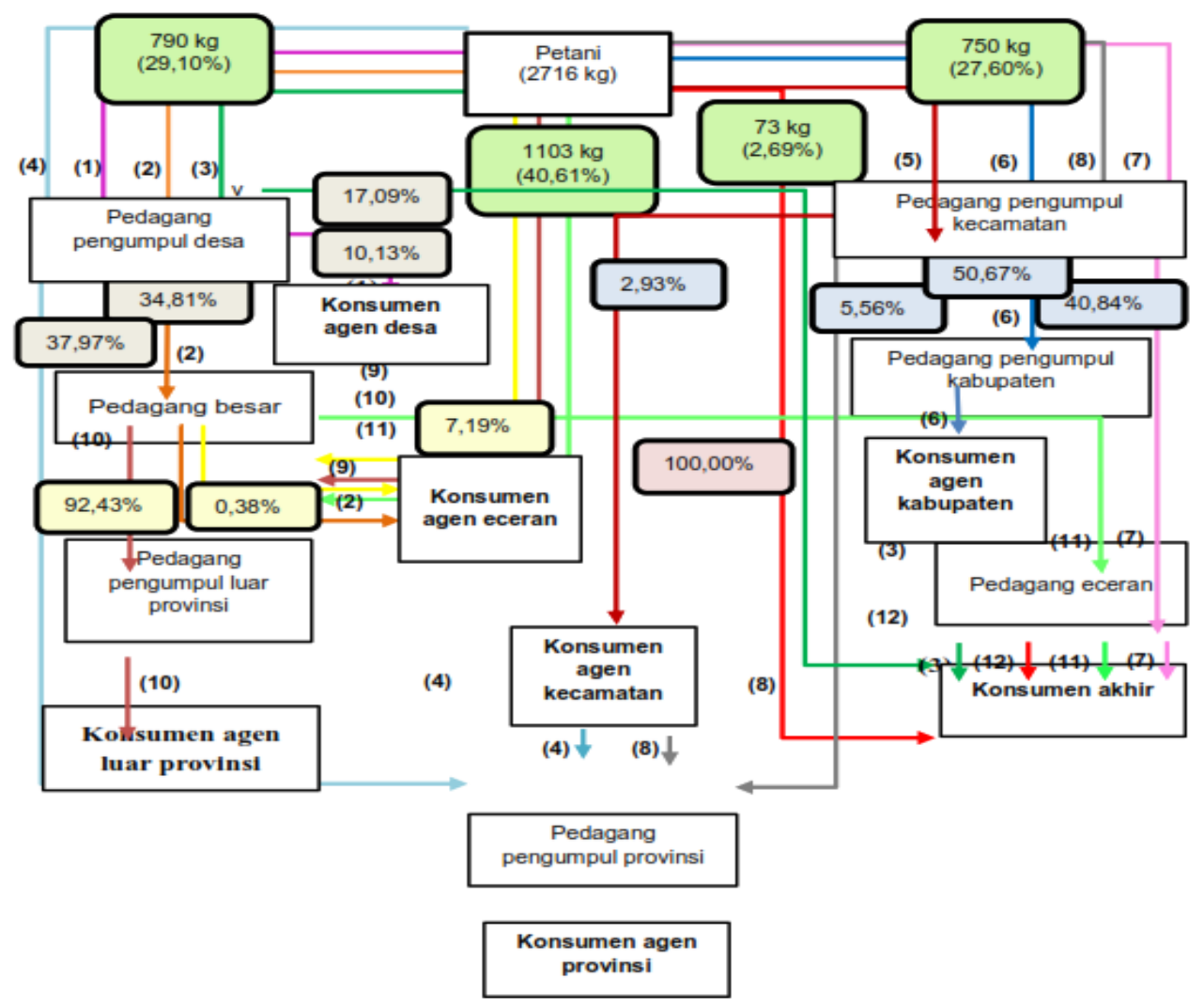

Gambar 1 Pola saluran pemasaran rata-rata per hari per musim tanam cabai rawit merah di Desa Brajan, Kecamatan Prambanan, Kabupaten Klaten pada tahun 2019. 
Tabel 4 Fungsi pemasaran cabai rawit merah pada setiap lembaga pemasaran

\begin{tabular}{lll}
\hline \multicolumn{1}{c}{ Lembaga } & Fungsi & \multicolumn{1}{c}{ Aktivitas } \\
\hline Petani & Pertukaran & Penjualan \\
& Fisik & Pengangkutan \\
Pedagang pengumpul & Fasilitas & Penanggungan risiko dan informasi pasar \\
desa & Pertukaran & Pembelian dan penjualan \\
& Fisik & Pengemasan dan penyimpanan \\
Pedagang pengumpul & Fasilitas & Penanggungan risiko, informasi pasar, dan sortasi \\
kecamatan & Pertukaran & Pembelian dan penjualan \\
& Fisik & Pengemasan, penyimpanan, pengangkutan, dan bongkar muat \\
Pedagang pengumpul & Fasilitas & Penanggungan risiko, informasi pasar, dan sortasi \\
kabupaten & Pertukaran & Pembelian dan penjualan \\
& Fisik & Pengemasan, penyimpanan, dan pengangkutan \\
Pedagang pengumpul & Fasilitas & Penanggungan risiko, dan informasi pasar \\
provinsi & Pertukaran & Pembelian dan penjualan \\
& Fisik & Pengemasan dan pengangkutan \\
Pedagang pengumpul & Fasilitas & Penanggungan risiko, dan informasi pasar \\
luar provinsi & Pertukaran & Pembelian dan penjualan \\
& Fisik & Pengemasan dan pengangkutan \\
Pedagang besar & Fasilitas & Penanggungan risiko dan informasi pasar \\
& Pertukaran & Pembelian dan penjualan \\
Pedagang eceran & Fisik & Pengemasan, penyimpanan, pengangkutan, dan bongkar muat \\
& Fasilitas & Penanggungan risiko, informasi pasar, dan sortasi \\
& Fisik & Pembelian dan penjualan \\
\hline
\end{tabular}

Tabel 5 Rekapitulasi marjin pemasaran, farmer's share, rasio antara keuntungan dan biaya, elastisitas transmisi harga, dan rata-rata penjualan per hari per musim tanam pemasaran cabai rawit merah di Desa Brajan pada tahun 2019

\begin{tabular}{ccccc}
\hline $\begin{array}{c}\text { Saluran } \\
\text { pemasaran }\end{array}$ & $\begin{array}{c}\text { Marjin } \\
\text { pemasaran }\end{array}$ & $\begin{array}{c}\text { Rasio keuntungan } \\
\text { terhadap biaya }\end{array}$ & Farmer's share (\%) & $\begin{array}{c}\text { Elatisitas transmisi } \\
\text { harga }\end{array}$ \\
\hline I & $4.303,33$ & 9,02 & 70,82 & 0,74 \\
II & 4470,00 & 9,97 & 70,02 & 0,73 \\
III & $3.970,00$ & 5,11 & 72,45 & 0,73 \\
IV & $5.970,00$ & 18,77 & 63,62 & 0,64 \\
V & $3.500,00$ & 3,17 & 75,35 & 0,79 \\
VI & $5.500,00$ & 10,53 & 66,05 & 0,70 \\
VII & $3.500,00$ & 4,98 & 75,35 & 0,79 \\
VIII & $4.000,00$ & 2,68 & 72,79 & 0,77 \\
IX & $3.500,00$ & 2,78 & 77,21 & 0,78 \\
X & $6.500,00$ & 4,31 & 64,59 & 0,67 \\
XI & $5.500,00$ & 5,44 & 68,31 & 0,71 \\
XII & $4.833,34$ & 5,15 & 71,84 & 0,76 \\
\hline
\end{tabular}

Marjin pemasaran merupakan selisih harga yang dibayar di antara lembaga pemasaran yang ada dalam setiap saluran pemasaran dari petani produsen hingga ke tangan konsumen akhir. Efisiensi pemasaran dapat dilihat dari saluran pemasaran yang memiliki marjin pemasaran terendah. Berdasarkan hasil analisis margin pemasaran, saluran V, VII, dan IX merupakan saluran yang memiliki margin terendah.

Hasil analisis $\mathrm{B} / \mathrm{C}$ ratio menunjukkan bahwa pada saluran IV memiliki nilai $\mathrm{B} / \mathrm{C}$ ratio paling tinggi, yaitu sebesar 18,77 . Nilai $B / C$ ratio yang tinggi dikarenakan keuntungan pada saluran ini lebih tinggi dan biaya pemasaran yang dikeluarkan paling rendah dibanding saluran lainnya. Nilai sebesar 18,77 artinya bahwa setiap Rp1,00 biaya pemasaran yang dikeluarkan memberikan keuntungan pemasaran sebesar Rp18,07/kg cabai rawit merah. Pada saluran VIII, nilai $\mathrm{B} / \mathrm{C}$ ratio paling rendah, yaitu sebesar 2,68 , artinya setiap $\mathrm{Rp} 1,00$ biaya pemasaran yang dikeluarkan pada saluran ini memberikan keuntungan pemasaran sebesar Rp2,68/kg cabai rawit merah.

Farmer's share paling tinggi terdapat pada saluran IX, yaitu sebesar $77,21 \%$. Farmer's share sebesar $77,21 \%$ memiliki arti bahwa bagian yang diterima petani sebesar $77,21 \%$ dari harga yang dibayarkan oleh konsumen akhir.

Berdasarkan perhitungan elastisitas transmisi harga, diperoleh data bahwa pada semua saluran pemasaran memiliki nilai elastisitas transmisi harga kurang dari satu $(E T i<1)$, sehingga interpretasinya, yaitu setiap perubahan harga sebesar $1 \%$ di tingkat petani akan menyebabkan perubahan harga kurang dari $1 \%$ di tingkat konsumen. Hal ini berarti bahwa respon perubahan harga cabai rawit merah di tingkat konsumen lebih kecil dibandingkan respon perubahan harga cabai rawit merah di tingkat petani.

Berdasarkan pembahasan tersebut, maka diketahui bahwa saluran VII dan IX merupakan saluran pema- 
saran yang paling efisien, namun petani umumnya tidak memilih saluran IX dikarenakan rata-rata penjualan per hari per musim tanam jumlahnya sangat rendah, yaitu sebesar $4,20 \mathrm{~kg}$, yaitu saluran VII dikatakan paling efisien dikarenakan merupakan salah satu saluran yang memiliki nilai total marjin paling rendah, farmer's share besar, rasio keuntungan terhadap biaya yang cukup besar, elastisitas yang mendekati nilai satu serta rata-rata jumlah penjualan per hari per musim tanam saluran VII cukup tinggi, yaitu sebesar 306,33 kg.

\section{KESIMPULAN}

Pendapatan petani baik anggota poktan dan non anggota komoditas cabai rawit merah di Desa Brajan menguntungkan atas biaya tunai. Pendapatan usaha tani cabai rawit merah yang diterima petani anggota poktan lebih tinggi dibandingkan petani non anggota poktan. Penjualan cabai rawit merah dilakukan oleh petani melalui lembaga perantara dan menghasilkan 12 saluran pemasaran dengan pemasaran yang mencakup lintas kabupaten dan lintas provinsi. Lembaga pemasaran komoditas cabai rawit merah terdiri dari pedagang pengumpul desa, pedagang pengumpul kecamatan, pedagang pengumpul kabupaten, pedagang pengumpul provinsi, pedagang pengumpul luar provinsi, pedagang besar, dan pedagang eceran.

Analisis efisiensi saluran pemasaran menunjukkan bahwa saluran VII merupakan saluran pemasaran yang paling efisien yang dapat dilakukan oleh petani cabai rawit merah di Desa Brajan. Saluran VII merupakan salah satu saluran yang memiliki nilai total marjin paling rendah, nilai farmer's share besar, rasio keuntungan terhadap biaya cukup besar, elastisitas transmisi harga yang mendekati satu, dan rata-rata penjualan per hari per musim tanam yang cukup tinggi.

\section{DAFTAR PUSTAKA}

Ardian R, Wayan S, Ketut RI. 2017. Perbandingan Pendapatan Usaha Tani Cabai Rawit dengan Menggunakan Pupuk Anorganik dan Pupuk Campuran (Organik dan Anorganik) (Studi Kasus di
Subak Kudungan, Desa Bontihing, Kecamatan Kubutambahan, Kabupaten Buleleng). E-Jurnal Agribisnis dan Agrowisata. 6(2): 240-248

Asmarantaka RW. 2014. Pemasaran Agrisnis (Agrimarketing). Bogor (ID): Institut Pertanian Bogor.

Arum. 2018. Kaleidoskop 2018: Awal 2018, Harga Cabai Rawit, Daging Ayam dan Telur Tinggi. [internet]. [diunduh tanggal 31 Mei 2019]. Tersedia pada: https://www.solotrust.com.

Azzaino Z. 1982. Pengantar Tatataniaga Pertanian. Bogor (ID): Institut Pertanian Bogor.

[BPS Kabupaten Klaten] Badan Pusat Statistik Kabupaten Klaten. 2018. Klaten Dalam Angka 2018. Klaten (ID): BPS Kabupaten Klaten.

[Kementan] Kementerian Pertanian. 2019. Statistika Pertanian 2019. Kementrian Pertanian Republik Indonesia. Jakarta (ID).

Kohls RL, Uhl JN. 2002. Marketing of agricultural Products. New Jersey (US): PrenticeHall.

Limbong WH, Sitorus P. 1987. Diktat Pengantar Tataniaga Pertanian. Bogor (ID): Institut Pertanian Bogor.

Purnama A. 2017. Harga Cabai Rawit di Klaten Anjlok, Ini Sebabnya. [internet]. [diunduh tanggal $31 \mathrm{Mei}$ 2019]. Tersedia pada: http://jogja.tribunnews.com.

[Pusdatin] Pusat Data dan Sistem Informasi Pertanian Kementerian Pertanian Republik Indonesia(ID). 2017. Statistik Pertanian 2017. [internet] [diunduh tanggal 23 November 2018]. Tersedia pada: http://pangan.litbang.pertanian.go.id.

Soekartawi. 2006. Analisis Usaha tani. Jakarta (ID): Universitas Indonesia Press.

Sondakh N, Jefrry OR. 2017. Faktor-Faktor yang Memengaruhi Peningkatan Pendapatan Usaha tani Cabai Rawit di Kabupaten Minahasa Selatan. Jurnal Bisnis dan Kewirausahaan. 13(2): 74-86

Sunarjono H. 2009. Bertanam 30 Jenis Sayur. Jakarta (ID): Penebar Swadaya. 